\title{
PERUBAHAN PROGRESIF DALAM PEMBELAJARAN PAI BERBASIS TEKNOLOGI INFORMASI DAN KOMUNIKASI
}

\author{
Oleh \\ Arief Rifkiawan Hamzah \\ UIN Sunan Kalijaga Yogyakarta \\ ariefrifkiawan@gmail.com
}

\begin{abstract}
Abstrack
This article explains about PAI learning by utilizing information and communication technology (ICT). PAI learning in Indonesia needs to be integrated with ICT, because it can open various avenues for teachers to more easily convey material and learners can also more easily understand. Illustrations which in the past were only made by teachers by drawing manually and made with paper, have now changed with the presence of a variety of good hardware and software. Learning by utilizing ICT can change the paradigm and teaching and learning process, both from the teacher and students. The progressive changes can be felt together, provided that all education providers support by providing various types of facilities.
\end{abstract}

Keywords: PAI Learning, ICT, and Progressive Change

\begin{abstract}
Abstrak
Artikel ini menjelaskan mengenai pembelajaran mata pelajaran pendidikan agama Islam dengan memanfaatkan teknologi informasi dan komunikasi (TIK).Pembelajaran pendidikan agama Islam di Indonesia perlu diintegrasikan dengan TIK, karena bisa membuka berbagai jalan bagi para guru untuk lebih mudah menyampaikan materi dan peserta didik juga bisa lebih mudah memahami. Ilustrasi-ilustrasi yang pada zaman dulu hanya dibuat oleh guru dengan menggambar secara manual dan dibuat dengan kertas, kini telah berubah dengan adanya berbagai macam hardware dan software yang bagus. Pembelajaran dengan memanfaat TIK dapat merubah paradigma dan proses belajar mengajar, baik itu dari pihak guru maupun peserta didik. Perubahan progresif bisa dirasakan bersama, dengan catatan semua penyelenggara pendidikan mendukung dengan menyediakan berabagai macam fasilitas.
\end{abstract}

\section{Kata Kunci: Pembelajaran PAI, TIK, dan Perubahan Progresif}

\section{A. PENDAHULUAN}

Pembelajaran PAI di berbagai lembaga pendidikan Islam telah melalui proses yang sangat panjang.Di Indonesia sendiri, PAI dijadikan sebagai mata pelajarandasar dasar yang wajib diajarkan kepada para peserta didikmuslim, mulai dari awal masuk sekolah hingga lulus sekolah. Mengingat urgennya pembelajaran PAI, maka pembelajarannya dari hari ke hari harus ada peningkatan dan perbaikanagar pesan yang ada di dalam 
PAI bisa tersampaikan dengan baik dan ditangkap baik pula oleh peserta didik.

Pembelajaran dalam UU Sisdiknas No 20 Tahun 2003 adalah proses interaksi peserta didik dengan pendidik dan sumber belajar pada suatu lingkungan belajar.Ada tiga poin yang ada di dalam pembelajaran, yaitu pendidik, peserta didik, dan sumber belajar, ketiga poin tersebut tidak akan bertemu atau tidak akan saling melengkapi jika tidak adanya interaksi, dan yang dibutuhkan adalah interaksi yang bersifat edukatif,jadi di antara ketiga poin tersebut bisa ditemukan di satu titik yang berupa interaksi.

Terkadang interaksi yang terjadi di antara ketiganya tidak bisa maksimal dan terkendala oleh berbagai hal, seperti halnya media yang dipakai dalam berinteraksi tidak relevan dengan mata pelajaran PAI dan lain sebagainya. Padahal teknologi informasi dan komunikasi semakin hari semakin berkembang pesat. Dengan perkembangannya,seharusnya para guru dalam pembelajaran PAI sudah bisa memanfaatkannya agar bisa maksimal. Seiring berkembangnyaTIK, ada satu poin yang belum banyak diperhatikan di dalam pembelajaran PAI, yaitupemanfaatan teknologi informasi dan komunikasi, pemanfaatan yang seharusnya dilakukan oleh para guru di dalam pembelajaran PAI, ternyata tidak sedikit yang belum memanfaatkannya secara optimal.

Menurut Sujoko, salah seorang Guru di SMP Negeri 2 Dagangan Madiun menjelaskan bahwa kurangnya pemanfaatan teknologi disebabkan dua hal, yaitu kurangnya sumber daya manusia yang kurang mumpuni dan kurangnya fasilitas yang mamadahi. ${ }^{1}$ Para guru pendidikan agama Islam masih banyak yang belum mampu untuk mengintegrasikan TIK dengan pembelajaran PAI. Hal itu disebabkan kurangnya pelatihan dan kurangnya fasilitas yang mendukung.

John L. Esposito dalam bukunya The Future of Islam mendeskripsikan hal berbeda mengenai Islam dan teknologi.Dalam acara pertemuan diplomat dan pebisnis Jepang, Esposito menceritakan bahwa banyak orangorang yang melontarkan dugaanmengenai ketidaksesuaian Islam dengan teknologi modern serta ketidakmampuan Islam melakukan pembaruan.Orang-orang Jepang sangsi jika umat Islam bisa merangkul modernisasi yang ditandai dengan perkembangan teknologi yang begitu canggih. $^{2}$

\section{Mengingat}

pentingnya penguasaan TIK bagi para guru, pemerintah melalui Kementerian Agama,Kementerian Pendidikan dan Kebudayaan, dan institusi lainnyamerespon dengan cepat. Pelatihan-pelatihan mengenai pemanfaatan teknologi informasi dan komunukiasi segera diselenggarakan setiap daerah.Misalkan Kemenag Bulungan melalui seksi Pendidikan Agama Islam menyelenggarakan pelatihan untuk para guru PAI mulai

1 Sujoko, "Pemanfaatan Teknologi Informasi dan Komunikasi sebagai Media Pembelajaran di SMP Negeri 1 Geger Madiun", Jurnal Kebijakan dan Pengembangan Pendidikan, Volume 1 No 1 Januari 2013, hlm. 72

${ }^{2}$ John L. Esposito, The Future of Islam, (New York: Oxford University Press, 2010), hlm. 88. 
dari SD/MI, SMP/MTs, dan

Kemudian pada Maret 2017 MUI yang bekerjasama dengan Pustekkom Kemendikbud menyelenggarakan pelatihan pengembangan media pembelajaran berbasis multimedia dan website kepada para pendidik agama Islam dan pendakwah. ${ }^{4}$ Sedangkan baru-baru ini tepatnyapada 28 Agustus 2018 Dinas Pendidikan Kota Batam juga mengadakan pelatihan pembelajaran berbasis IT di gedung Gurindam Dinas Pendidikan Kota Batam. $^{5}$

Serangkaian pelatihan tidak berhenti di pada para guru, tetapi para pengawas dan operator juga dilatih dalam memanfaatkan teknologi informasi dan komunikasi.Pelatihan bagi pengawas PAI ini deprogramkan oleh Direktorat Pendidikan Agama Islam yang baru dimulai dari Kota Banda Aceh dalam rangka Peningkatan Kompetensi Guru dan Pengawas

3 Pelatihan yang diselenggarakan di Aula Disperindakop Kabupaten Bulungan ini diikuti oleh 40 guru Pendidikan Agama Islam, yang terdiri dari 22 guru SD/MI, 10 guru SMP/MTs, dan 8 Guru SMA/MA.https://kaltim.kemenag.go.id/berita/r ead/283406. Diakses pada 27 Agustus 2018.

${ }^{4}$ Pelatihan ini dilaksanakan selama tiga hari dari tanggal 15-17 Maret 2017 di auditorium Pustekkom, yang diikuti oleh 33 peserta.http://pustekkom.kemdikbud.go.id/pelat ihan-pengembangan-media-pembelajaranuntuk-tenaga-pendidik-agama-danpendakwah/. Diakses pada 27 Agustus 2018.

5 Pelatihan yang diikuti oleh 50 guru PAI SD/MI dan SMP/MTSs berawal dari pengamatan bahwa sejumlah guru belum seutuhnya penggunaan teknologi informasi.https://jateng.kemenag.go.id/warta/b erita/detail/guru-pai-ikuti-workshop-

pengayaan-kurikulum-berbasis-ict/. Diakses pada 28 Agustus 2018.
Bidang TIK. ${ }^{6}$ Kemudian Kemenag Kebumen juga menyelenggarakan Bimtek yang bertajuk "Pengembangan Keprofesian Berkelanjutan" bagi 67 peserta dari pengawas dan opretor.Dalam Bimtek ini, materi yang dibahas ialah evaluasi diri, peningkatan kompetensi tenaga pendidikan agama Islam, pelatihan kompetensi online, dan lain sebagainya. ${ }^{7}$

Beberapa pelatihan tersebut merupakan bagian kecil dari usaha Kemenag dan Kemendikbud serta instansi lain dalam meningkatkan kemampuan para pengawas, guru, dan operator dalam memanfaatkan TIK. Masih banyak pelatihan-pelatihan serupa yang diselenggarakan untuk meningkatkan kemampuan para pengawas, guru, dan operator dalam memanfaatkan TIK.Utamanya adalah guru, karena para gurulah yang terlibat langsung dalam proses pembelajaran pendidikan agama Islam di kelas.

Di sisi lain, pelatihan-pelatihan tersebut untuk mengkonter setereotip orang-orang Jepang mengenai Islam dan teknologi. Dengan adanya pelatihan itumenunjukkan bahwa umat

${ }^{6}$ Pengawas PAI merupakan salah satu bagian penting dalam serangkaian pelaksanaan program Pengembangan Keprofesian Berkelanjutan (PKB), sehingga para pengawas PAI harus menguasai TIK agar bisa menyelesaikan tugasnya dengan baik. http://pendis.kemenag.go.id/index.php?a=detil \&id=8919. Diakses pada 29 Agustus 2018 .

${ }^{7}$ Kepala Seksi Pendidikan Agama Islam Kemenag Kebumen mengatakan, melalui bimtek ini diharapkan para guru PAI dapat memahami dan menguasai teknologi informasi secara on line, profesional dan memiliki kemampuan leadership. http://www.kebumenkab.go.id/index.php/publi c/news/detail/5751. Diakses pada 28 Agustus 2018. 
Islam mengangap bahwa Islam dan teknologi tidaklah bertentengan, tetapi justru menjadi pendukung dalam pembelajaran agama Islam dan dakwah.Asumsi-asumsi setereotip yang menurut Esposito berangkat dari mindset bahwa Islam berbeda dengan agama-agama lain, sebenarnya dengan usaha ini umat Islam berusaha membuat pembaruan.

Esposite berpendapat bahwa setiap mahasiswa yang mempelajari sejarah agama-agama, seluruh agamaagama besar di dunia terus berubah dan akan mengalami perubahan.Hal itu bisa dilihat dari sifat dasar manusia dan sejarah yang dinamis, perubahanpun sebagai sebuah keniscayaan. Bahkan di kalangan fundamentalis juga mengalami perubahan dan selalu menginginkan pembaruan.Dalam hal ini, yang patut dipertanyakan dan didiskusikan menurut Esposito bukanlah mengenai bisa berubah atau tidak, tetapi mengenai seberapa besar perubahan dan pembaruan itu terjadi. ${ }^{8}$

Oleh karena itu, untuk menggapai perubahan dan pembaruan dalam pembelajaran PAI, diperlukan dukungan teknologi informasi dan komunikasi.Pemanfaatan TIK perlu dimaksimalkan dalam setiap materi pendidikan agama Islam agar setiap peserta didik dapat menangkap pesan dan mengamalkan setiap meteri yang dipelajari.Dengan memanfaatkan TIK secara maksimal, diharapkan outputnya bisa maksimal juga.

\section{B. KEDUDUKAN TEKNOLOGI INFORMASI DAN KOMUNIKASI DALAM PEMBELAJARAN PAI}

Islam sebagai agama yang rahmatan lil'alamin menyampaikan pesan yang sangat bermanfaat bagi umat Islam di seluruh dunia melalui Nabi Muhammad, pesan yang disampaikan tersebut berkaitan dengan pendidikan yaitu tentang pendidikan sepanjang hayat (life long education). Ini artinya bahwa pendidikan Islam bersifat kontinyu dan akan dilakukan secara kontinyu pula.

Di dalam pendidikan Islam, pembelajaran PAI yang dijadikan sebagai sarana untuk mewarisi budaya secara sosial dan mengembangkan potensi peserta didik secara individualsudah dilakukan secara kontinyu dan saat ini sudah berusia beradab-abad. Seiring bergulirnya waktu, semakin hari semua aspek mengalami kemajuan dan perkembangan yang imbasnya sangat dirasakan dalam pembelajaran PAI, tentu saja untuk mengimbangi segala aspek yang berkembang, maka pembelajaran PAI dituntut untuk melakukan inovasi baru secara internal maupun eksternal.

Pembelajaran PAI saat ini tidak lagi bisa dipenuhi dengan pendekatan yang konvensional, oleh karena itu dengan berkembangnya teknologi informasi dan komunikasi, sudah selayaknya lembaga-lembaga pendidikan Islam memperkenalkan dan memulai penggunaan TIK sebagai

${ }^{8}$ John L. Esposito, The Future of Islam, hlm. 88-89. 
basis pembelajaran yang mutakhir. ${ }^{9}$ Penggunaan dan pemanfaatan teknologi informasi dan komunikasi diharapkan bisa menunjang pembelajaran PAI agar PAI semakin mudah dipahami dan bermakna bagi peserta didik selama hidupnya.

Saat ini kedudukan TIK di tengah-tengah masyarakat tidak hanya dijadikan sebagai penunjang untuk mengembangkan potensi diri sendiri, tetapi sudah merambah ke pengguna secara masa atau kolektif dan digunakan dalam bidang apapun, terutama dalam bidang pendidikan. TIK dalam bidang pendidikan Islam yang berkedudukan sebagai jembatan menuju realitas pembelajaran PAI, sudah seharusnya dimanfaatkan oleh para guru dalam mengajar. TIK bisa menjembatani guru dan peserta didik untuk memperluas pengetahuan, menjadikan pembelajaran PAI dinamis dan fleksibel, mengatasi keterbatasan ajar dan seterusya. ${ }^{10}$ Selain itu, TIK juga berkdudukan menjembatani dalam batasan ruang, jarak, dan waktu, sharing information, virtual university. ${ }^{11}$

Ketika seorang guru berencana untuk lebih memaksimalkan pembelarajan PAI, maka dia yang awalnya mempunyai pengetahuan sedikit bisa bertambah dengan memanfaatkan kecanggihan TIK, pembelajaran yang tadinya statis dan

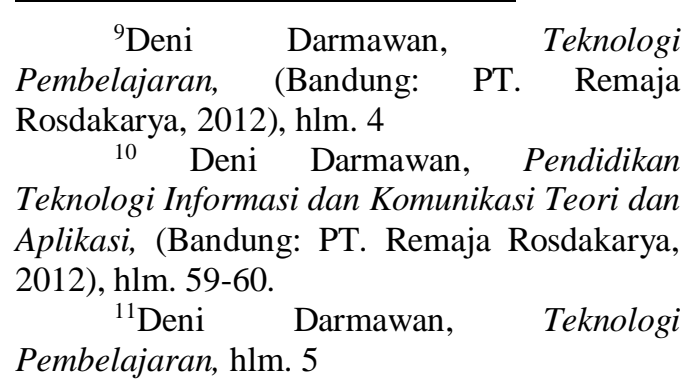

kolot bisa menjadi dinamis dan fleksibel melalui teknologi informasi dan komunikasi. Melalui TIK juga guru sudah tidak lagi ketakutan dalam mengembangkan hal bahan ajar, karena bisa mengakses sebanyak-banyaknya dalam bentuk digital. TIK semata-mata sebagai jembatan yang menyambungkan permasalahan menuju solusi yang konkrit.

\section{PEMANFAATAN TIK DALAM PEMBELAJARAN PAI}

Sebagai usaha dalam pengembangan pembelajaran, sudah dipersiapkan tenaga-tenaga yang secara khusus untuk mengelolanya, namun tenaga-tenaga ini diberi pelatihan dalam bekerjasama dengan subject specialistsuntuk mengembangkan sistem pembelajaran pada lapis mikro (classroom)dan makro (educational syistem's levels) atau sistem pendidikan. ${ }^{12}$

Pengembangan yang dilakukan oleh para ahli dalam pembelajaran PAI terutama yang berlapis mikro atau yang berkaitan dengan ruang dan waktu, dapat menunjukkan bagi para guru saat ini bahwa dengan teknologi informasi, mereka tidak perlu lagi direpotkan dengan masalah-masalah pembelajaran, karena dengan TIK yang diwakili oleh media pembelajaran, kehidupan pembelajaran PAI tidak lagi terdengar menakutkan atau membosankan.

Sedangkan pembelajaran secara makro ini berkaitan dengan sistem, yang terdiri dari beberapa komponen agar pembelajaran PAI yang selama ini

\footnotetext{
${ }^{12}$ Yusufhadi Miarso, Menyemai Benih Teknologi Pendidikan, (Jakarta: Kencana, 2011), hlm.157
} 
berjalan tidak terhambat. Salah satu persoalan yang ada di sini adalah kurangnya waktu atau tidak adanya waktu secara rutin untuk mengikuti pembelajaran PAI secara utuh, sehingga diharuskan ada alternatif lain agar peserta didik bisa memahami PAI secara mandalam.

\section{Pembelajaran PAI Mikro (classroom)}

Pembelajaran PAI secara mikro berkaitan dengan tempat dan waktu, yaitu pembelajaran PAI ditempatkan di ruang kelas. Di dalam kelas, pendidik bisa mengajar dengan memanfaatkan media pembelajaran,pemanfaatan media dalam situasi ini untuk menunjang tercapainya tujuan tertentu dan pemanfaatannya disesuaikan dengan proses belajar mengajar dalam situasi kelas. ${ }^{13}$ Artinya media pembelajaran digunakan dalam waktu yang tepat untuk menyampaikan bahan ajar, agar proses belajar mengajar bisa secara sistematis terlaksana.

Di era teknologi informasi dan komunikasi dewasa ini, perkembangan teknologi informasi dan komunikasi di dalam pendidikan lebih difokuskan pada pengembangan dan pemakaian media pembelajaran, karena media pembelajaran dewasa ini dianggap sebagai salah satu faktor yang menentukan keberhasilan proses pembelajaran. Dalam proses pembelajaran

PAI, pemanfaatanmedia pembelajaran memiliki kontribusi dalam meningkatkan mutu dan kualitas

13 Yudhi Munadi, Media Pembelajaran Sebuah Pendekatan Baru, (Jakarta: Gaung Persada Press, 2012), hlm. 208 pengajaran, maka tidak heran jika saat ini pendidikan semakin berkembang.

Adanya media pembelajaran, selain membantu guru dalam menyampaikan materi, media juga memberikan nilai yang lebih bagi keberhasilan proses pembelajaran, hal ini berlaku bagi segala jenis media, baik yang canggih dan mahal, ataupun media yang sangat sederhana dan murah. Semakin baik memanfaatkannya, maka sebaik baik pula hasilnya, mahal atau murah tidak menjadi jaminan dalam keberhasilan pembelajaran.

Jenis media yang sering digunakan dalam kegiatan pembelajaran PAI adalah media visual, audio, dan audio-visual.Media visual diartikan sebagai media yang bisa dilihat. Media visual terdiri atas media yang dapat diproyeksikan (projected visual) dan media yang tidak dapat diproyeksikan (non projected visual). Contoh dari media yang bisadiproyeksikan seperti overhead projector (OHP), slide (film bingkai), flimstrip (film

rangkai), opaque projector, video dan film. ${ }^{14}$ Sedangkan contoh dari media yang tidak dapat diproyeksikan berupa gambar/foto yang konkret, sketsa, diagram, grafik, kartun, realita, buku, peta, globe dan sebagainya. ${ }^{15}$

Media audio adalah media yang melibatkan indra pendengaran dalam pembelajaran PAI. Pesan yang disampaikan dituangkan ke dalam

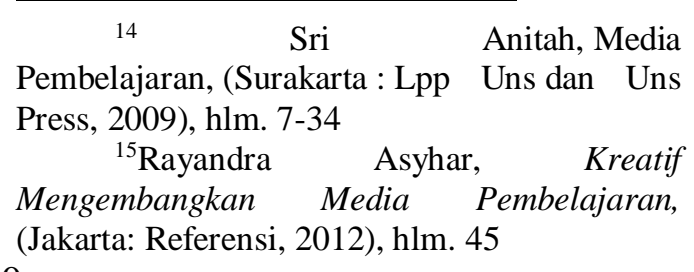


lambang-lambang auditif, baik verbal (lisan), maupun non verbal. Ada beberapa jenis media audio, yaitu radio, alat perekam magnetik, piringan hitam, dan laboratorium bahasa. ${ }^{16}$ Media audio visualadalah jenis media yang digunakan dalam pembelajaran PAI dengan melibatkan indra pendengaran dan penglihatan. Beberapa jenis media audio visual, diantaranya film bingkai, film, televisi, video, media transparansi, permainan dan simulasi. ${ }^{17}$

Guru yang bertugas sebagai orang yang membuat desain pembelajaran PAI di kelas, maka dia harus dengan jeli mengintegrasikan media ke dalam rencana pembelajaran.Hal-hal yang harus diperhatikan dalam merencanakan pembelajaran dengan memanfaatkan media pembelajaran adalah tujuan yang akan dicapai, materi pembelajaran yang mendukung tercapainya tujuan itu, strategi belajar mengajar, dan waktu yang tersedia. ${ }^{18}$ Media pembelajaran yang dipakai disesuaikandengan ketiga hal tersebut, yaitu sesuai dengantujuan yang akan dicapai, materi atau pesan yang disampaikan, strategi pembelajaranya, dan sesuai dengan waktu yang tersedia. Dengan terintegrasinya media ke dalam proses pembelajaran PAI, maka informasi atau materi yang disampaikan kepada peserta didik bisa tersampaikan dengan baik dan terjalin komunikasi yang baik antara peserta didik, guru, dan materi.

\footnotetext{
${ }^{16} \mathrm{Ibid}$.

${ }^{17}$ Ibid.

${ }^{18}$ Yudhi Munadi, Media Pembelajaran Sebuah Pendekatan Baru, hlm. 208
}

Contoh pemanfaatan teknologi informasi dan komunikasi dalam pembelajaran PAIketika presentasi, dengan adanya presentasi guru bisa membuat slide dengan Microsoft Power Point, peserta didik menjadi lebih mudah mengerti materi yang diajarkan. Slide presentasi yang baik adalah yang menggunakan contoh gambar ataupun animasi untuk membantu proses pemahaman peserta didik, selain itu guru bisa memakai LCD projector untuk menampilkan slide yang sudah dibuat tadi dan dibuat lebih kreatif dengan menampilkan berbagai konten multimedia, seperti gambar, video, suara, dan sebagainya. Selain guru, peserta didikpun bisa pula memanfaatkanya, dia bisa mendemonstrasikan kegiatan eksperimen melalui LCD dengan tujuan untuk memperlihatkan cara yang dilakukan dalam eksepimen tersebut.

\section{Pembelajaran PAI Makro (educational syistem's levels)}

Dalam skala makro, yang meliputi seluruh sistem pendidikan Islam, ada sebuah problem yang berkaitan dengan sistem pendidikan Islam, misalkan persoalan waktu, ada di antara sekian banyak manusia hidup di dunia yang belum mendapatkan kesempatan untuk belajar secara merata, persoalan kesempatan ini diusahakan pemecahan persoalan dengan melakukan pengembangan dan pengelolaan pembelajaran dan menginovasi pembelajaran, hasil dari pengembangan tersebut berupa SMP Terbuka dan UT. ${ }^{19}$

19 Yusufhadi Miarso, Menyemai Benih Teknologi Pendidikan, (Jakarta: Kencana, 2011), hlm. 554 
Selain persoalan waktu, ada lagi persoalan tentang pembelajaran PAI yang belum matang dan merata, hal ini bisa memanfaatkan media pembelajaran PAI yang bisa dilakukan di luar kelas, pemanfaatan media di luar kelas bisa dibedakan menjadi tiga kelompok, yaitu pemanfaatan media secara terkontrol, secara bebas, dan jumlah sasarannya. ${ }^{20}$ Pembelajaran PAI dengan terbaginya tiga kelompok ini bisa menjadikannya lebih luas, mendalam dan mengena dalam pembahasannya.

a) Pemanfaatan secara terkontrol Maksud dari pemanfaatan media secara terkontrol adalah bahwa media yang digunakan dalam krgiatankegiatan pembelajaran PAI yang diatur secara sistematik untuk mencapai tujuan tertentu. Hasil belajar mereka dievaluasi secara teratur. ${ }^{21}$ Untuk keperluan evaluasi ini pembuat program media perlu menyediakan alat evaluasi tersebut.pemanfaatan media dalam bentuk ini bisa juga dipakai dalam bentuk pembelejaran jarak jauh dengan menggunakan internet sebagai penyambung komunikasinya.

Memanfaatkan internet untuk proses pembelajaran jarak jauh (kelas virtual). Kelas virtual ini sudah menjadi sesuatu yang baru dan tren di era globalisasi sekarang. Karena kelas virtual atau jarak jauh ini mmiliki beberapa keuntungan dan kelebihan, seperti peserta didik dapat mengekspresikan bersosialisasi, saling sharing pengetahuan, meningkatkan kreativitas,

\footnotetext{
${ }^{20}$ Yudhi Munadi, Media Pembelajaran Sebuah Pendekatan Baru, hlm. 209

${ }^{21}$ Ibid.
}

dan menumbuhkan dan mengembangkancara belajar yang mandiri.

b) Pemanfaatan secara bebas

Pemanfaatan media secara bebas adalah media itu digunakantanpa dikontrol atau diawasi, seperti halnya media-media yang dimanfaatkan oleh masyarakat luas yang diperoleh dengan cara membelinya, dengan harapan media itu dapat digunakan orang dan cukup efektif untuk mencapai tujuan pembelajaran PAI.Masyarakat sendiri yang menentukan sejauh mana pemanfaatan media-media tersebut dalam rangka memenuhi kebutuhan untuk pembelajaran PAI. ${ }^{22}$

Media yang bisa digunakan secara bebas dan tanpa kontrol dari pihak lembaga pendidikan Islam adah radio, televisi, HP dan seterusnya. Pemanfaatan siaran radio yang memuat materi-materi tentang agama Islam baik secara dialog ataupun dengan metode ceramah,sedangkan siaran televisi yang mempunyai dampak baik dan buruk masih banyak masyarakat yang mempermasalahkan televisi dijadikan sebagai media pembelajaran PAI, terlepas dari itu semua, televisibisa menunjang pemebalajran PAI, seperti halnya acara-acara ceramah, hafidz cilik, film-film sejarah, dan seterusnya. Program-program itu disiarkan dengan maksud untuk menyampaikan pesanpesan pendidikan agama Islam danbagi orang yang memanfaatkan media ini kebanyakan tidak dikontrol oleh penyelenggara siaran.

c) Pemanfaatan media berdasarkan jumlah sasarannya
${ }^{22}$ Ibid. 
Pemanfaatan media dilihat dari segi julamlahnya dapat diklasifikasikan menjadi tiga, yaitu secata individu, kelompok, dan masal. Klasifikasi ini dalam pembelajaran PAI bisa ditunjang dengan media yang tidak sama, melainkan harus ditunjang dengan media yang berbeda-beda, untuk skala kecil atau individu akan lebih mudah mengakomodirnya, sedangkan untuk kelompok lebih sulit, terlebih jika mencapai masal, untuk mengatasi hal itulah media pembelajaran dimanfaatkan.

Pertama,media bisa digunakan secara person. Ada beberapa media yang bisa digunakan secara person untuk menunjang pembelajaran PAI, media untuk person biasanya dilengapi dengan petunjuk pemanfaatan yang jelas sehingga orang dapat menggunakanya dengan mandiri, ${ }^{23}$ artinya orang itu tidak perlu bertanya kepada orang laintentang bagaimana cara menggunakanya, alat apa yang diperlukan, dan bagaiman mengetahui bahwa ia telah berhasil dalam belajar, seperti halnya modul pembelajaran.

Kedua,media dapat digunakan secara berkelompok. Bagian kedua ini diklasifikasikan menjadi dua kelompok yaitu kelompok skala kecil dan kelompok skala besar. Kelompok skala kecil berjumlah 2-8 peserta didik, sedangkan kelompok skala besar terdiri dari 9-40 peserta didik,kelebihan kelompok skala kecil atai besardalam menggunakan media adalah bahwa kelompok tersebutbisa melakukan diskusi tentang bahan atau materi yang sedang dipelajari. Media yang digunakan secara kelompok harus

${ }^{23} \mathrm{Ibid}$. memenuhi beberapa persyaratan yaitu suara yang disajikan oleh media itu harus cukup keras sehingga semua anggota kelompok dapat mendengarnya, gambar atau tulisan dalam media itu harus cukup besar sehinggah dapat dilihat oleh semua anggota kelompok itu, dan perlu adanya penyajian yang dapat memperkeras suara dan membesarkan gambar (proyektor). ${ }^{24}$

Ketiga,media dapat juga digunakan secara masal.Media yang digunakan untuk jumlahnya puluhan, ratusan, bahkan ribuan harus bisa digunakan secara bersama-sama. Media yang dirancang seperti ini biasanya disiarkan melalui pemancar, seperti radio televisi, atau digunakan dalam ruang yang besar. Sebelum memanfaatkan media ini, terlebih dulu peserta didik diberi bahan tercetak yang isinya berupa tujuan pembelajaran, garis besar isi, petunjuk, dan tindak lanjut, dan baham dari sumber-sumber lainnya untuk pendalaman. ${ }^{25}$ Dengan adanya lembar petunjuk, peserta didik bisa dengan mudah untuk mengikuti alur atau materi yang telah disajikan melalui media secara masal.

Dengan demikian, media pembelajaran bisa memperluas cakrawala materi yang disampaikan di dalam kelas, memberikan pengalaman yang beragam, kokrit dan nyata, bisa mengefektifkan mengefisienkan pembelajaran, memecahkan masalah baik mikro maupun makro. ${ }^{26}$ Maka

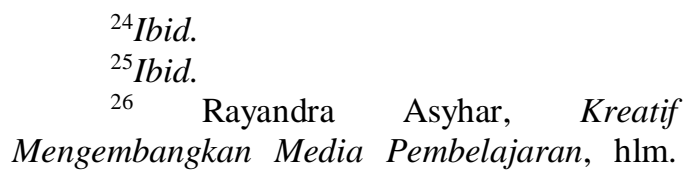
Mengembangkan Media Pembelajaran, hlm. 41 
jelaslah bahwa teknologi informasi ini bisa menjadi jembatan pembelajaran PAI dari problem yang serius menuju ke solusi konkrit.

\section{PEMANFAATANTIK BERBASIS KOMPUTER DALAM PEMBELAJARAN PAI}

Teknologi informasi merupakan suatu proses perkembangan teknik, metode dan media komunikasi untuk bertukar informasi antar manusia. Pemanfaatan teknologi informasi diperuntukkan bagi peningkatan kinerja lembaga pendidikan dalam upayanya meningkatkan kualitas sumber daya manusia Indonesia. Hal ini membantu guru dan pengajar lainnya agar tidak lagi disibukkan oleh pekerjaanpekerjaan operasional, yang sesungguhnya dapat digantikan oleh komputer.

Komputer merupakan hasil rancangan manusia yang di dalamnya terdapar kombinasi antara teks, suara, warna, gambar, video mampu membawa perubahan yang signifikan bagi segala bidang pekerjaan umat manusia, salah satunya adalah di bidang pendidikan. Khususnya di dalam pembelajaran PAI, computer bisa digunakan sebagai penunjang guru untuk menyampaikan materi-materi pendidikan agama Islam kepada peserta didik.Selain guru, peserta didik juga bisa memanfaatkannya secara mandiri untuk memahami konsep-konsep yang ada di dalam pendidikan agama Islam. ${ }^{27}$ Teknologi berbasis computer ini bisa digunakan oleh siapa saja yang

${ }^{27}$ Deni $\quad$ Darmawan,
Teknologi Informasi dan Komunikasi Teori dan
Aplikasi, hlm. 91

memang berkenan memanfaatkannya dan bisa mengoperasikannya, jadi apabila ada seorang guru atau peserta didik yang sama-sama ingin memanfaatkannya dalam pembelajaran PAI, harus mendalami dulu tentang ilmu komputer.

Pemanfaatan pembelajaran berbasis komputer ini informasi yang akan disampaikan kepada peserta didik dikemas dalam bentuk digital, bukan berbentuk cetakan.Dalam pembelajaran berbantuan komputer, peserta didik berhadapan langsung dengan komputer dan berinteraksi secara intens, interaksi terjadi secara individual masingmasing peserta didik. ${ }^{28}$ selama proses interaksi yang intens tersebut, di situlah peserta didik menyerap informasi yang telah dikemas dan disajikan dengan berbantuan komputer. Hal ini tentu lebih menarik dan membawa imajinasi peserta didik ke tingkat yang lebih tinggi.

Misalkan dalam pembelajaran PAI temanya tentang sejarah Nabi, jika disajikan hanya dengan bercerita, peserta didik tentu kurang begitu menghayati dan mengambil intisari dari kisah tersebut, namun berbeda jika penyampaian materi tersebut dengan memanfaatkan komputer dan disajikan ke dalam bentuk gambar-gambar atau bahkan video. Ini akan membawa peserta didik berinteraksi dengan tampilan-tampilan tersebut.

Dengan demikian, teknologi informasi dan komunikasi berbasis komputer tersebut dapat memberikan keuntungan dalam efisien waktu dan tenaga serta keefektifan pembelajaran PAI.Komunikasi yang dibangun oleh

\footnotetext{
${ }^{28}$ Ibid.
} 
guru dan peserta didik merupakan dasar dari pembelajaran PAI, ${ }^{29}$ sesuatu yang dasar tentunya harus didesain dengan matang dan kokoh, dimulai dari pesan yang akan disampaikan, caranya, perlengkapannya, dan hasilnya, semua ini dalam pembelajaran PAI dilakukan atas dasar kesengajaan dan terarah. Jadi pembelajaran PAI jika hanya ada komputer tanpa dilengkapi dengan halhal yang telah disebutkan tadi, tentu pembelajaran tidak akan terarah dan tidak efektif. Oleh karena itu dengan adanya komputer, guru tidak diperkenankan melupakan hal-hal yang substansial yaitu mencapai tujuan pembelajaran PAI.

\section{E. SISTEM- \\ SISTEMPENYAMPAIAN}

Sistem-sistem yang dipakai di dalam pembelajaran diklasifikasikan menjadi tiga, di antara ketiga sistem tersebut hanya membutuhkan biaya yang murah danada yang mahal. Semakin mahal biaya yang dikeluarkan, maka semakin lengkap pula fasilitas yang bisa dipakai oleh peserta didik di dalam pembelajaran PAI, biasanya biaya yang mahal ini memberikan fasilitas berupa jaringan yang luas. Di antara tiga sistem itu adalah sebagai berikut:

\section{Pertama sistem jaringan} gabungan, yaitu sistem yang terdiri dari berbagai terminal dan dihubungkan dengan komputer sentral atau pusat. Penyambungan antara terminal-terminal yang dipakai oleh peserta didik disambungkan melalui

${ }^{29}$ Dimyati \& Mudjiono, Belajar \& Pembelajaran, (Jakarta: PT. Rineka Cipta, 2013), hlm.143 telepon atau kabel-kabel, sehingga peserta didik bisa menerima instruksi dari guru melalui terminal-terminal tersebut, sistem ini dipakai hanya untuk keperluan instruksional. ${ }^{30}$

Kedua sistem jaringan gabungan, sistem ini memang mirip dengan sistem yang pertama, yang membedakan adalah bahwa sistem ini bisa memberikan fasilitas kepada guru atau peserta didik untuk saling berinteraksi, sistem ini bisa juga digunakan untuk latihan. ${ }^{31}$ Sistem ini tidak memandang jarak dan waktu, semua pihak bias menggunakannya untuk berinteraksi dalam pembelajaran Agama Islam dengan lebih luas.

Ketiga sistem independen atau berdiri sendiri, ini merupakan sistem yang dijalankan oleh suatu microprosesor dan masing-masing unit terbebas dari unit-unit yang lain. ${ }^{32}$ Sistem ini juga dapat diterapkan dalam pembelajaran Agama Islam yang ditekankan pada meteri-materi tertentu. Peserta didik dapat meningkatkan pemahamannya secara individu mengenai meteri-materi tertentu, baik secara kognitif maupun afektifnya.

Sistem-sistem tersebut dapat dimanfaatkan dengan sempurna dalam pembelajaran pendidikan Agama Islam, dengan memperhatikan setiap materi yang membutuhkan system tersebut. Setiap perbedaan materi yang disampaikan oleh guru bias memanfaatkan salah satunya yang cocok untuk pengembangan pembelajaran, agar para pembelajaran

${ }^{30}$ Ronald H. Anderson, Pemilihan dan Pengenmbangan Untuk Media Pembelajaran, (Jakarta: Rajawali Pers, 1987), hlm. 201

${ }^{31}$ Ibid.,hlm. 203

${ }^{32}$ Ibid.,hlm. 204 
bisa berkontribusi terhadap perkembangan kognitif maupun afektif peserta didik.

Berbagai merek komputer, laptop, maupun android yang sudah dikoneksikan dengan jaringan internet sangat membantu membuka cakrawala pembelajaran pendidikan agama Islam. Pembelajaran dengan memanfaat TIK, dapat diintegrasikan dengan berbagai macam disiplin ilmu, baik itu dengan geografi, psikologi, antropologi, dan lain sebagainya.Koneksitas antar berbagai ilmulah yang sebenarnya bisa diberikan oleh TIK di era milenial ini, siapapun dan apapun pembelajarannya bisa diintegrasikan dengan baik.

\section{F. PERUBAHAN PROGRESIF DALAM PEMANFAATAN TIK}

Teknologi informasi dan komunikasi selalu dikembangkan oleh para ahli sesempurna mungkin. Setiap orang bisa melihat perkembangan itu bukan dalam jaraklima tahunan seperti pergantian presiden, namun lebih cepat dari itu. Teknologi informasi dan komunikasi semakin cepat berubah dan semakin canggih meninggalkan teknologi abad pertangahan maupun sebelumnya.Kekayaan manusia di zaman ini dan kekuatan riset yang optimis mampu merubah teknologi informasi dan komunikasi di masa lalu menjadi lebih sempurna.

Manusia yang hidup dalam orde lama, orde baru, dan reformasi tentu bisa merasakan berbagai perkembangan. Para guru merasakan bahwa dulu belum ada pembelajaran pendidikan Agama Islam berbasis komputer dan jaringan, yang ada hanya papan tulis dan kapur dengan metode ceramahnya yang khas. Namun ketika teknologi informasi dan komunikasi dikembangkan dengan begitu cepat, para guru maupun peserta didik masih banyak yang belum cukup memahaminya.

Dampak dari perkembangan itu ialah berubahnya kurikulum, yang saat ini diterapkan kurikulum 2013 dengan pendekatan ilmiahnya. Kurikulum pendidikan agama Islam tidak lepas dari pemanfaatan komputer dan jaringannya, karena pendekatan ilmiah yang diterapkan sangat membutuhkan bantuan itu dalam mengeksplorasi berbagai macam materi pendidikan agama Islam.

Setiap sekolah yang menerapkan Kurikulum 2013 harus akrab dengan teknologi informasi dan komunikasi, baik dalam pembelajaran PAImaupun pembelajaran lain. Hal ini merupakan membawa perubahan atau pergeseran yang signifikan, pergeseran ini bukan ke arah regresif, tetapi ke arah progresif.Dikatakan progresif karena untuk memberikan ruang lebih luas bagi para guru dan para peserta didik dalam mengembangkan setiap potensinya.

Perubahan-perubahan yang terjadi di dalam pembelajaran bisa dicermatibahwa pembelajaran tidak hanya bisa dilakukan di ruang kelas, tetapi juga secara virtual. Fasilitas fisik ke fasilitas jaringan kerja,dari waktu siklus ke waktu nyata, dari manual ke otomatis ${ }^{33}$ sudah mulai banyak diterapkan dan dirasakan perubahannya di lembaga-lembaga pendidikan.

\footnotetext{
${ }^{33}$ Deni Darmawan, Teknologi Pembelajaran, hlm. 57
} 


\section{G. PENUTUP}

Pemanfaatan teknologi informasi dan komunikasi dalam pembelajaran PAI dilakukan secara mikro (classroom) dan makro (educational syistem's levels) atau sistem pendidikan. Sistem mikro memanfaatkan media pembelajaran sebagai penunjang untuk memaksimalkan pembelajaran, sedangkan secara makro sistem pendidikan dilakukan dengan memanfaatkan teknologi pendidikan yang berbentuk software dan hardware.

Perubahan progresif yang terjadi dalam pemanfaatan teknologi informasi dan komunikasi adalah dari konvensional menuju ke modern, dari era paper ke era komputer, dari era konservatif ke era fleksibel, dari era individu ke era kolektif, dari batas ke tanpa batas. Semua itu merupakan kemudahan yang diberikan oleh teknologi modern untuk pembelajaran pendidikan agama Islam.

\section{DAFTAR PUSTAKA}

Anderson, Ronald H., Pemilihan dan Pengenmbangan Untuk Media Pembelajaran, Jakarta: Rajawali Pers, 1987.

Anitah,

Sri, Media

Pembelajaran, Surakarta : LPP

UNS dan UNS Press, 2009.

$\begin{array}{cr}\text { Asyhar, Rayandra, } & \text { Kreatif } \\ \text { Mengembangkan } & \text { Media } \\ \text { Pembelajaran, } & \text { Jakarta: }\end{array}$

Referensi, 2012.

Darmawan, Deni, Teknologi

Pembelajaran, Bandung: PT.

Remaja Rosdakarya, 2012.
Pendidikan

Teknologi Informasi dan Komunikasi Teori dan Aplikasi, Bandung: PT. Remaja Rosdakarya, 2012.

Dimyati \& Mudjiono, Belajar \& Pembelajaran, Jakarta: PT. Rineka Cipta, 2013.

John L. Esposito, The Future of Islam, (New York: Oxford University Press, 2010.

Miarso, Yusufhadi, Menyemai Benih Teknologi Pendidikan, Jakarta: Kencana, 2011.

Munadi, Yudhi, Media Pembelajaran

Sebuah Pendekatan Baru,

Jakarta: Gaung Persada Press, 2012.

Sujoko, "Pemanfaatan Teknologi Informasi dan Komunikasi sebagai Media Pembelajaran di SMP Negeri 1 Geger Madiun", Jurnal Kebijakan dan Pengembangan Pendidikan, Volume 1 No 1 Januari 2013.

Web:

www.kaltim.kemenag.go.id www.pustekkom.kemdikbud.go.id www.jateng.kemenag.go.id www.pendis.kemenag.go.id www.kebumenkab.go.id 